\title{
0 agronegócio e a atuação da burguesia agrária: considerações da luta de classes no campo
}

\author{
The agribusiness and the agrarian bourgeoisie: \\ considerations of class struggle in the field
}

\author{
Ilena Felipe Barros \\ Assistente social; doutora em Serviço Social; pesquisadora da questão agrária; docente do departamento de \\ Serviço Social da Universidade Federal do Rio Grande do Norte, Natal/RN, Brasil. ilenafb@hotmail.com
}

\begin{abstract}
Resumo: O presente artigo origina-se da tese de doutoramento em Serviço Social pela UFPE. $\mathrm{O}$ artigo tece algumas considerações acerca do agronegócio e do papel da burguesia agrária neste setor. O campo brasileiro apresenta uma permanente luta de classes, entre aqueles que detêm os meios de produção (burguesia agrária) e aqueles/ as que detêm apenas a força de trabalho (trabalhadores/as rurais). Quem são os representantes dessa burguesia agrária? Como estão representados nos poderes Legislativo, Executivo e Judiciário? Quais suas organizações? Como interferem no desenvolvimento econômico do país?
\end{abstract}

Palavras-chave: Burguesia agrária. Trabalhadores rurais. Agronegócio.
Abstract: This article originates from the $\mathrm{PhD}$ thesis in Social Service by UFPE. The article presents some considerations about agribusiness and the role of the agrarian bourgeoisie in this sector. The Brazilian countryside presents a permanent class struggle between those who hold the means of production (agrarian bourgeoisie) and those who only hold the labor force (rural workers). Who are the representatives of this agrarian bourgeoisie? How are they represented in the legislative, executive and judicial branches? What are your organizations? How do they interfere in the economic development of the country?

Keyword: Agrarian bourgeoisie. Rural workers. Agribusiness.

\section{Introdução}

\section{atual fase de financeirização e mundialização do capital tem atingido todos os setores da economia, inclusive a agricultura 1 brasileira. Há em curso, no campo, dois modelos de desenvolvi- mento em plena disputa política e econômica: de um lado o agronegócio e de outro a agricultura familiar e camponesa. O que interessa neste artigo é}


discutir: como o agronegócio se apropria da terra e das riquezas naturais? Quem são os representantes políticos e sociais do agronegócio? Quem é a burguesia agrária que mantém esse modelo de agricultura? Como ela se organiza e como se articula no Legislativo federal? As respostas a tais questões podem elucidar quem compõe essa burguesia agrária (ou também conhecidos pelas suas frações de classe: ruralistas, patronato rural, agroindustriais, empresários rurais, grande produtor rural, latifundiários, elite agrária, grandes proprietários de terras, usineiros, pecuaristas), sua identidade, suas estratégias, suas organizações, suas articulações políticas, seus espaços institucionais de representação política, sua rede de relações sociais e seus interesses.

Essa avalanche do capital na agricultura foi em decorrência da sua crise desencadeada nos anos 1970, que forjou um novo ciclo de acumulação - a mundialização e a financeirização, integrando o capital em escala mundial, através das empresas multinacionais e transnacionais. Ou seja, o centro do capital não está mais centralizado nos países ricos, mas em todo lugar onde as empresas se instalam. Essa é a nova ordem do capital que gerou uma nova divisão internacional do trabalho e redesenhou a organização territorial da produção capitalista. Os interesses do capital se apropriam dos meios de produção nacionais e os internacionalizam. Em decorrência, a luta de classe ganha dimensão também internacional.

$\mathrm{O}$ desenvolvimento desse capital mundializado atingiu a agricultura e revelou uma associação entre indústria e agricultura, entre grandes extensões de terra e empresas transnacionais, entre proprietários de terras e capitalistas internacionais. Nesse processo, o capital se territorializou e intensificou a expropriação e a expulsão dos camponeses para as cidades, instalando os grandes complexos agroindustriais no campo, via monocultura, para exportação, alcançando a ampliação e a reprodução do capital.

No Brasil, esse processo de penetração do capital mundializado na agricultura ganhou novo impulso de desenvolvimento a partir do segundo mandato de Fernando Henrique Cardoso e na sequência no governo de Luiz Inácio Lula da Silva, quando funda-se uma estratégia de retorno no investimento 
em complexos agroindustriais (já realizados por ocasião da modernização conservadora no período de 1960 a 1980) associados a grande propriedade privada da terra para responder à balança comercial externa. Essa estratégia se consolida através da inserção do capital financeiro na agricultura, sob a prioridade do agronegócio, valorizando o mercado de terras e as exportações de produtos primários.

A agricultura brasileira passou por um longo período de modernização técnica (1960-80) sem alteração na estrutura fundiária. Com a Constituição Federal de 1988, muda a propriedade fundiária e esta é elevada à sua condição de função social da terra. Mas o instrumento constitucional não foi suficiente para haver transformações no campo, nem realizar a reforma agrária demandada pelos movimentos sociais que lutam pela terra.

Nos anos 1990-2000, a agricultura é chamada a responder às exigências do ajustamento constrangido e ao endividamento interno e externo. Nesse momento, dá-se um novo impulso à estratégia externa de agronegócio e dinamização do setor agroexportador, que se consolida no governo de Luiz Inácio Lula da Silva, associada à nova política econômica mundial de financeirização do capital. Assim, o governo difunde a estratégia de gerar saldos de comércio exterior, no sentido de suprir o déficit da conta-corrente, priorizando a agricultura capitalista do agronegócio na agenda macroeconômica externa e na política agrícola interna.

\section{Particularidades da acumulação do capital no campo: 0 agronegócio em debate}

Em virtude do movimento de mundialização e expansão do capital sobre todos os setores da economia, identifica-se, na atualidade, a existência de dois modelos de agricultura, que estão em disputa no cenário brasileiro. De um lado, o agronegócio ou agribusiness, representado pela burguesia agrária e articulado ao capital financeiro internacional; do outro, a agricultura camponesa com base na produção familiar e de alimentos, sustentada pelos/ 
as trabalhadores/as rurais assentados, sitiantes, posseiros, arrendatários, parceiros, meeiros ${ }^{1}$ e pequenos produtores rurais.

Nas últimas décadas, a agricultura em todo mundo tem sofrido as incursões do capital financeiro no sentido de produzir em escala global sob as regras do mercado e da acumulação. No caso específico da agricultura, o capital financeiro tem controlado a produção e a comercialização dos produtos agrícolas. Destaca-se nesse cenário a aquisição de empresas de diferentes ramos da produção agrícola, por bancos com os excedentes do capital financeiro. Isso acarretou um crescimento surpreendente dessas empresas que tiveram um investimento de um capital acumulado que estava fora dos processos agrícolas, contribuindo para dominarem a produção, o comércio, os insumos, as máquinas agrícolas, os medicamentos, os agrotóxicos, ${ }^{2}$ as ferramentas etc. Em segundo lugar, essas empresas, fortalecidas pelo capital financeiro e favorecidas pela dolarização da economia mundial, entraram nas economias nacionais e adquiriram as empresas e a produção agrícola local. Outra forma de controle utilizada pelo capital financeiro tem sido as normas e regras impostas pelas IFMs (especialmente o Banco Mundial, FMI e $\mathrm{OMC}$ ) quanto à produção e comércio agrícola, obedecendo aos interesses das grandes empresas e obrigando os governos locais a liberar o comércio dos produtos.

Nessa dinâmica do capital financeiro na agricultura há, ainda, uma forte dependência quanto ao crédito bancário e à industrialização. Esses créditos financiam o domínio da agricultura pela indústria em todo mundo. Nessa lógica globalizada, os governos locais diminuíram ou praticamente abandonaram as políticas públicas de comércio local e para agricultura

1. O meeiro é aquele que aluga uma parte da terra do proprietário para cultivar produtos de subsistência e paga o aluguel com $50 \%$ da produção agrícola que conseguiu produzir.

2. De acordo com a Lei $n^{\circ} 7.802$, de 11/7/1989, regulamentada pelo Decreto $n^{\circ} 4.074$, de 4/1/2002, os agrotóxicos são "produtos e componentes de processos físicos, químicos ou biológicos destinados ao uso nos setores de produção, armazenamento e beneficiamento de produtos agrícolas, nas pastagens, na produção de florestas nativas ou implantadas, e em outros ecossistemas e também ambientes urbanos, hídricos e industriais; cuja finalidade seja alterar a composição da flora e da fauna, a fim de preservá-las da ação danosa de seres vivos considerados nocivos. São considerados, também, como agrotóxicos, substâncias e produtos como desfolhantes, dessecantes, estimulantes e inibidores de crescimento" (Brasil, 2002). 
camponesa de base familiar. Os governos liberaram os mercados nacionais e executaram as políticas de ajuste estrutural do neoliberalismo em favor das grandes transnacionais, através de isenções fiscais nas importações e exportações e taxas de juros favoráveis ao modelo de agricultura capitalista.

Com a crise do capital em 2008, os investimentos mais significativos para os grandes grupos econômicos foram aplicar seus capitais voláteis em ativos fixos como terra, minério, matéria-prima agrícola, água, território rico em biodiversidade e em produção de energias renováveis, como usinas de etanol e hidroelétricas.

Como afirma Stédile (2013, p. 23),

Esses capitais financeiros se dirigiam às bolsas de mercadorias agrícolas e de minérios para aplicar seus ativos e assim especular no mercado futuro ou simplesmente transformar o dinheiro em mercadorias futuras. Esse movimento gerou uma elevação exagerada nos preços dos produtos agrícolas negociados pelas empresas nas bolsas mundiais de mercadorias [...] eles são resultado dos movimentos especulativos e do controle oligopólico dos mercados agrícolas por essas grandes empresas.

Sob a hegemonia do capital financeiro, as empresas transnacionais concentraram o controle da produção e do comércio de produtos agrícolas, principalmente a agroindústria de soja, milho, cana-de-açúcar e laticínios e o monocultivo de eucalipto para celulose e carvão (siderurgia). Esse controle favoreceu o aumento dos preços dos produtos agrícolas e dos insumos em âmbito mundial, obtendo lucros extraordinários e, consequentemente, gerando a falência de pequenos e médios produtores locais que não conseguem produzir no mesmo padrão imposto pelas empresas capitalistas. A concentração da produção agrícola atinge um pequeno número de proprietários de terra articulados com as empresas. No Brasil, " $10 \%$ de todos os estabelecimentos agrícolas do país controlam $80 \%$ do valor da produção" (Stédile, 2013, p. 25).

Essas empresas estrangeiras expandem seus negócios na agricultura capitalista controlando um volume significativo de hectares de terras no Brasil, 
tendo como prioridade a produção de soja em todas as regiões brasileiras: a cana-de-açúcar no Centro-Sudeste; a celulose no sul da Bahia, Espírito Santo e Mato Grosso do Sul; a madeira para carvão na região Norte e Minas Gerais; frutas irrigadas no semiárido; camarão em cativeiro no litoral do Nordeste; pecuária nas regiões degradadas e fronteiras agrícolas; algodão no Centro-Oeste (Stédile, 2013, p. 29).

Os governos brasileiros vêm sistematicamente criando condições macroeconômicas favoráveis à expansão do agronegócio, proporcionando a aliança da propriedade fundiária com o capital financeiro, de modo a ampliar e proteger as terras improdutivas para futuras transações e acumulação do capital, o que impede a reforma agrária.

A partir de 2008, a crise internacional afeta a economia brasileira pela enorme fuga de capital e altera a política econômica, forçando modificações do sistema cambial. A política de comércio exterior se transforma, e a estratégia encontrada é gerar saldos comerciais e suprir o déficit da conta-corrente. Volta-se, então, para investimento em exportações de produtos agrícolas e minerais. Dessa forma, a agricultura capitalista, sob a forma do agronegócio, é fundamental para capturar o excedente econômico e recuperar a economia brasileira.

Durante o segundo governo de Fernando Henrique Cardoso (19992002), os investimentos no agronegócio são reforçados através das seguintes iniciativas: a) um programa prioritário de investimento em infraestrutura territorial, visando a criação de economias externas que incorporassem novos territórios, meios de transporte e corredores comerciais ao agronegócio; b) um explícito direcionamento do sistema público de pesquisa agropecuária (Empresa Brasileira de Pesquisa Agropecuária - Embrapa), operando em sincronia com empresas multinacionais do agronegócio; c) uma regulação frouxa do mercado de terras, de modo a deixar fora do controle público as terras devolutas, mais aquelas que declaram não cumprir a função social, além de boa parte das autodeclaradas produtivas; d) a mudança da política cambial torna a economia do agronegócio competitiva junto ao comércio internacional e funcional a estratégia de ajustamento macroeconômico; e) a 
provisão de crédito rural nos Planos Safra é retomada em vigor no período de 2003-10 (Delgado, 2013, p. 64-65).

Essa lógica de reprodução do capital no campo, que se desenvolve no controle da produção agrícola, nos insumos e na expansão dos produtos para exportação só foi possível em função da aliança que se produziu entre as empresas multinacionais com os fazendeiros e grandes proprietários de terra. Os fazendeiros se associam subordinadamente às corporações do capital financeiro e dispõem de grandes extensões de terra, da depredação do meio ambiente e da superexploração do trabalho agrícola, muitas vezes com uso da força em condições análogas ao trabalho escravo. Exemplo disso são as empresas estabelecidas no Brasil produtoras de cana-de-açúcar, fruticultura, soja, pecuária, arroz etc.

Essa voracidade do capital sobre a agricultura tem provocado um aquecimento no mercado de terras no Brasil, exatamente nas áreas que concentram a monocultura, o latifúndio e o agronegócio. Quando o capital se apropria da terra, este o faz num processo de concentração da riqueza que tem na propriedade privada da terra um caráter rentista, próprio do desenvolvimento capitalista brasileiro. Desse modo,

Ao mesmo tempo em que este desenvolvimento avança reproduzindo relações especificamente capitalistas, implantando o trabalho assalariado, produz também, igual e contraditoriamente, relações camponesas de produção, a peoagem e suas diferentes formas de "escravidão pela dívida" etc., todas necessárias a sua lógica de desenvolvimento. (Oliveira, 2010, p. 287)

Ressalta-se que, desde a ditadura militar, os governos brasileiros vêm investindo na agricultura, através da expansão de complexos agroindustriais, articulado com o capital financeiro internacional. Já nesse período ocorre um processo de articulação entre o capital agroindustrial, o sistema de crédito à agricultura, à agroindústria e à propriedade fundiária no sentido de estruturar e sustentar a modernização conservadora da agricultura. Nesse sentido, "o mercado de terras e o crédito rural, sob o patrocínio do Estado, são peças 
essenciais para possibilitar a estratégia de capital financeiro na agricultura" (Delgado, 2013, p. 60-61).

É nesse momento que o capital aplicado à terra proporciona a acumulação desse mesmo capital, tendo a renda da terra como elemento fundante para sua reprodução. Seguindo a mesma lógica, o sistema de crédito rural para a agricultura contribuiu para a construção de complexos agroindustriais e para cumprir a função do capital em ampliar as taxas de lucro, agora em variados setores e ramos da produção agrícola.

No atual modelo de agricultura brasileira, o agronegócio se constitui uma das estratégias da política macroeconômica do governo federal. Como nos informa Bruno (2009, p. 114),

O agronegócio despontou como palavra política unificadora de interesses das classes e grupos dominantes no campo e expressão do processo de construção da hegemonia e de renovação dos espaços de poder e de dominação.

No mercado mundial do agronegócio, o Brasil precisa exportar e importar, mesmo que tenha condições favoráveis para produzir aquilo que importa. Os capitalistas internacionais se beneficiam e aumentam seus lucros com as exportações. O Brasil tem um lugar privilegiado no mundo capitalizado, sendo um dos principais fornecedores e exportadores de alimentos, minério de ferro, aviões, produtos florestais (celulose, papel, madeira e seus derivados).

O modelo do agronegócio tem dominado a propriedade privada da terra por empresas transnacionais, mas também os recursos hídricos, as florestas e os minérios, gerando fortes contradições entre os interesses capitalistas e os do povo que vive no campo. Acrescenta-se ainda o controle das sementes e mudas, colocando em risco a soberania alimentar, a biodiversidade, o meio ambiente e a agricultura camponesa e familiar. As consequências são devastadoras para a vida no campo, pois aumentam as migrações internas e o inchaço das médias e grandes cidades, especialmente nas periferias, loteamentos e bairros populares. 
A estrutura das classes sociais no campo também se alterou com esse novo modelo de agricultura: da parte da classe dominante, tem-se: a) há um grupo que é composto por capitalistas empresariais, que controlam os meios de produção e a produção de commodities para exportação. Esse grupo é composto por cerca de 450 mil estabelecimentos agrícolas e possuem 300 milhões de hectares; b) outro grupo é formado por proprietários de terras, na maioria improdutivas. Esse grupo é subjugado às empresas transnacionais que podem comprar ou arrendar essas terras; também são atrasados, com forte aparato de milícias particulares, jagunços, pistoleiros e com esquema de controle político, econômico, administrativo e judiciário da região onde se localizam suas propriedades. Da parte da classe trabalhadora, tem-se: a) os assalariados rurais permanentes em fazendas do agronegócio acima de mil hectares totalizam cerca de 400 mil; assalariados rurais temporários e outros 1,8 milhão de pessoas nas propriedades de 500 a 2 mil hectares; b) os camponeses em regime de agricultura familiar que possuem pequenas áreas em assentamentos ou áreas menores de cem hectares somam aproximadamente 4,8 milhões. Esses agricultores familiares apresentam uma renda mensal capaz de sustentar suas famílias e acessar linhas de créditos do Pronaf; c) há os camponeses pobres, sem-terra, vivendo como diaristas ou da cultura de subsistência, em condições inadequadas e insuficientes para manter a família. Estes totalizam cerca de 3,8 milhões de famílias de camponeses; d) há ainda um grupo que vive em condições análogas à escravidão, totalmente à margem do atual regime de produção agrícola (IBGE, 2006).

Na concepção de Delgado (2010, p. 93), o agronegócio "é uma associação do grande capital agroindustrial com a grande propriedade fundiária". Essa associação realiza uma aliança estratégica com o capital financeiro, perseguindo o lucro e a renda da terra, sob o patrocínio da política de Estado, ou seja, conta com a mediação do Estado.

A hegemonia do agronegócio sustenta-se no modelo agroexportador de commodities, em grande escala e com uso intensivo de agrotóxicos e transgênicos, não permitindo outra forma de produção agrícola. São complexos agroindustriais com grandes investimentos em tecnologia e mecanização; formas de gestão e controle da força de trabalho assalariada; e ainda, um 
aparato midiático que dissemina as ideias necessárias para convencer que esse é o único modelo viável de produção de alimentos.

De acordo com Fernandes (2013, p. 191-192), o agronegócio é “a expressão capitalista da modernização da agricultura, que tem se apropriado dos latifúndios e das terras do campesinato para se territorializar". Esse modelo de desenvolvimento na agricultura dificulta a realização da reforma agrária demandada pelos movimentos de luta.

É um sistema de produção baseado na monocultura, na mão de obra escrava e na grande propriedade protegida pelo Estado. É um dos elementos essenciais para compreender a perversa concentração fundiária e o grau de extrema pobreza que ainda hoje se verificam no meio rural, principalmente no Nordeste.

Essa forma de produzir foi possibilitada pela aliança de frações da classe dominante: empresas transnacionais, capital financeiro, grandes proprietários de terra, agroindústrias que controlam a produção e a circulação de commodities. Essa articulação de classe garantiu o controle dos preços agrícolas, a circulação dos produtos, o monopólio da terra e dos recursos naturais, controle do mercado interno e externo e, consequentemente, a apropriação da renda da terra e o lucro produzido na agricultura. Nesse processo, implantaram-se grandes extensões de monoculturas, com alta produtividade, uso intensivo de agrotóxicos, exploração abusiva da força de trabalho, mecanização do processo produtivo etc. Essa forma de produzir também atingiu a produção científica e tecnológica da pesquisa agropecuária.

Nessa lógica de produção, há um uso intensivo de mecanização, que expulsa força de trabalho para aumentar a produtividade do trabalho agrícola, cujo sentido é de uma agricultura com número reduzido de trabalhadores rurais e exploração aviltante. Também é reconhecido o uso abusivo de agrotóxicos, como forma de aumentar a rentabilidade da lavoura e do trabalho à base de venenos, sem nenhum controle, causando todo tipo de degradação do meio ambiente ${ }^{3}$, destruindo a fertilidade natural do solo e

3. Em 2011, mais de trinta entidades da sociedade civil brasileira - movimentos sociais, entidades ambientalistas e de estudantes, organizações ligadas à área da saúde e grupos de pesquisadores — lançaram 
seus micro-organismos, contaminando as águas dos lençóis freáticos e a atmosfera, além da destruição do território e da cultura dos povos originários.

\section{Identidade e atuação da burguesia agrária brasileira}

O conceito de burguesia agrária parte da concepção teórico-metodológica dialética, do pensar a luta pela posse da terra e pela reforma agrária como momento da luta de classes no Brasil. Trata-se, em nossa acepção, de apreender o significado e a contraposição das classes sociais no campo, especialmente o papel da burguesia agrária no processo de acumulação capitalista, que permite a essa classe a apropriação privada dos meios de produção e do excedente produzido socialmente. Portanto, a conceituação de burguesia agrária refere-se à posse dos meios de produção (essencialmente a terra) com o propósito de valorização do capital, através da apropriação indevida dos frutos do trabalho não pago de outrem.

De acordo com os escritos de Engels (1847), em Princípios do comunismo, a burguesia constitui "a classe dos grandes capitalistas que, em todos os países desenvolvidos, detém, hoje em dia, quase que exclusivamente, a propriedade de todos os meios de consumo e das matérias-primas e instrumentos (máquinas, fábricas) necessários à sua produção". E, em nota a edição inglesa de 1888 do Manifesto do Partido Comunista designou a burguesia como "a classe dos capitalistas modernos, proprietários dos meios da produção social e empregadores do trabalho assalariado” (Bottomore, 2001, p. 38).

\footnotetext{
a Campanha Permanente contra os Agrotóxicos e pela Vida. A campanha pretende abrir um debate com a população sobre a falta de fiscalização no uso, consumo e venda de agrotóxicos, bem como sobre a contaminação dos solos e das águas, além de denunciar os impactos dos venenos na saúde dos trabalhadores, das comunidades rurais e dos consumidores nas cidades. Afora denunciar as mazelas causadas pelas empresas $\mathrm{e}$ pelo uso de agrotóxicos, é preciso construir formas de restringir o uso de venenos e de impedir a sua expansão, propondo projetos de lei, portarias e iniciativas legais e jurídicas. Outro campo de atuação da campanha é o anúncio da possibilidade de construção de um modelo agrícola diferente, baseado na agricultura camponesa e agroecológica. Uma das ações da campanha foi o lançamento do filme $O$ veneno está na mesa, de Silvio Tendler, que vem se constituindo forte instrumento de mobilização e de formação em comunidades rurais e urbanas para fomentar o debate sobre o uso dos agrotóxicos na agricultura brasileira e suas consequências para a saúde da população (Campanha contra os Agrotóxicos, 2011).
} 
Para apreender a atualidade da burguesia agrária na perspectiva crítica, é imprescindível analisar as classes sociais não apenas pelo lugar que ela ocupa na produção capitalista, mas também do ponto de vista ideológico e subjetivo, das suas estratégias de manutenção do poder e da acumulação do capital. E, nessa perspectiva, a burguesia agrária significa opressão, exploração, violência, intolerância. Da mesma forma que "sem-terra", "quilombola", "ribeirinho", "boia-fria" identifica o lugar dos oprimidos, dos espoliados, dos explorados e expropriados da propriedade da terra, dos recursos naturais, dos direitos sociais e humanos, da vida digna (Bruno, 2009).

A burguesia agrária é formada e identificada como a classe dominante, aquela que possui os meios de produção, ou seja, a terra, os recursos naturais, o capital agrário, capital agroindustrial, capital agrocomercial, capital financeiro e se organiza através de grandes empresas capitalistas que administram direta e indiretamente a produção agrícola de monocultura e mantém um número considerável de trabalhadores assalariados, que sustentam o processo de acumulação e reprodução capitalista. Esta apropria-se do trabalho excedente e da mais-valia. Essa classe se opõe ao campesinato, seus movimentos sociais, suas lideranças e suas organizações, através dos mais diversos instrumentos ideológicos de coerção e violência.

Vale salientar que a burguesia agrária não se vincula notadamente e apenas à produção agrícola direta, isto é, ao espaço da fazenda administrando a produção. Ela se amplia para todos os setores que estão articulados ao primeiro: fabricação de insumos, comercialização, fertilizantes, agrotóxicos, máquinas e ferragens agrícolas e, para além disso, em bancos, conglomerados de empresas, transnacionais, agroindústrias, grupos econômicos em plena conexão de diferentes capitais, em âmbito regional, nacional e internacional. Parte dessa burguesia já tinha relação direta com o campo, seja por herança da família ou por fazer parte de algum grupo de fazendeiros locais; outra parte caracteriza-se pela integração de capitais, como um negócio para atrair melhores perspectivas de valorização e acumulação do capital, sem nunca ter tido aptidão para a agricultura.

Como procuramos evidenciar acima, um dos grupos que compõem a burguesia agrária é formado pelos latifundiários que mantêm grandes 
extensões de terras sem nenhuma produção e/ou uso de trabalho assalariado, o chamado latifúndio improdutivo, que pode se modificar, depender dos interesses do capital e da região em que estiver situado. O latifúndio é uma reserva de valor, uma renda capitalizada, que poderá se metamorfosear a qualquer tempo em capital agrícola produtivo, arrebanhado por alguma empresa transnacional do agronegócio. Enquanto improdutivo, participa do capital financeiro, gerando lucro, através da especulação no mercado de terra e, portanto, da renda fundiária.

Um estudo da Cepal (1985) trata as classes sociais no campo de acordo com a economia agrícola, separando o que é economia camponesa e economia empresarial. O elemento de diferenciação das classes é a contratação ou não de força de trabalho. O setor camponês está identificado com aquele que não contrata pessoal ou, quando o faz, é por um período curto da safra agrícola, como um trabalho complementar ao familiar. Já o setor empresarial compreende unidades produtivas, com a contratação de trabalho assalariado em grandes fazendas de monocultura. Ainda há outro setor que é chamado de intermediário que trata dos agricultores de transição, "uma categoria fluida, que possui uma capacidade de acumulação reduzida, e errática".

Assim, esse estudo da Cepal (1985) caracteriza o setor camponês como aquele composto de

unidades bastante heterogêneas, este foi separado em diferentes categorias, a saber: a) o de infrassubsistência: o potencial produtivo da unidade é insuficiente para a alimentação familiar e tem uma superfície arável inferior a 4 hectares; b) o de subsistência: o potencial produtivo ultrapassa ao requerido para a alimentação, mas é insuficiente para gerar um fundo de reposição e tem uma superfície arável entre 4 e 8 hectares; c) o estacionário: a unidade obtém um excedente acima do produzido para o consumo e é equivalente ao fundo de reposição, como também para certas reservas eventuais; d) o excedentário: gera excedentes acima de suas necessidades de reprodução simples.

Quando se trata do setor empresarial, a Cepal (1985) estabelece a seguinte distinção: 
a) pequenos empresários: têm uma força de trabalho familiar significativa, porém, inferior à contratada, a qual varia entre 500 e 1.500 jornadas por ano; b) médios empresários: a força de trabalho familiar é pouco significativa e a mão de obra contratada varia entre 1.250 a 2.500 jornadas anuais; c) grandes empresários: a força de trabalho familiar carece de significação, em contraposição à mão de obra contratada que excede a 2.500 jornadas salariais por ano.

Autores contemporâneos ${ }^{4}$ identificam um setor patronal no campo que compreende aqueles grupos econômicos possuidores de terra e de produção e estão representados por cerca de 450 mil estabelecimentos ou empresários capitalistas, controlando 300 milhões de hectares e toda produção de commodities para exportação. Nesses estabelecimentos trabalham 400 mil assalariados nas propriedades acima de mil hectares, e outros 1,8 milhão nas propriedades de 500 a 2 mil hectares, totalizando 2,2 milhões de trabalhadores assalariados no agronegócio (Stédile, 2013, p. 31).

Há uma heterogeneidade quanto aos grupos e frações de classe que compõem a burguesia agrária, sejam indivíduos diretamente ligados à produção agrícola "da porteira para dentro", até grupos e indivíduos que têm e/ou veem no meio rural uma maneira de valorização, reserva de capital e ativo financeiro: a terra. Essa diversidade contribui para a complexa rede de relações entre as classes sociais no campo.

A pesquisa realizada por Bruno (2009) $)^{5}$ sintetiza o discurso e a hegemonia ideológica da burguesia agrária e do agronegócio na sociedade brasileira. Designa o lugar da classe social dominante e sua expressão no cenário econômico, político, social e cultural. Segundo a autora, os grupos que compõem o agronegócio estão representados pelas entidades patronais de abrangência nacional e várias em âmbito regional. Algumas em destaque: Associação Brasileira de Agronegócio (Abag), Movimento Nacional dos Produtores (MNP), Organização das Cooperativas Brasileiras (OCB), Sociedade

4. José Eli da Veiga (2013), Ariovaldo Umbelino (2013), João Pedro Stédile (2013).

5. A socióloga e professora da Universidade Federal Rural do Rio de Janeiro (UFRRJ), Regina Bruno, realizou importantes pesquisas sobre a identidade do patronato rural e sua atuação no agronegócio. Ver Bruno (2009). 
Rural Brasileira (SRB), União Democrática Ruralista (UDR), Confederação Nacional da Agricultura e Pecuária do Brasil (CNA), Sociedade Nacional de Agricultura (SNA).

A burguesia agrária não se constitui uma classe social homogênea, e sim diferenciada e complexa, com frações e grupos sociais que se movimentam na produção agrícola, em uma ampla rede de sociabilidades e relações.

De acordo com Bruno (2009, p. 114), as entidades da burguesia agrária estabelecem cinco dimensões do agronegócio: como sinônimo de união, de sucesso e de geração de riqueza; como expressão da modernidade e de um novo modelo de desenvolvimento; crença na ausência de outras alternativas históricas além do agronegócio; valorização de si e desqualificação do outro; o imperativo de uma maior institucionalidade e da construção de novos espaços de representação.

Nessa perspectiva, o agronegócio aparece como sucesso absoluto, riqueza garantida para a classe dominante do campo, capaz de agregar todos os setores da produção agrícola com competência e desenvolvimento seguro para as cidades onde vem sendo implantado. Há, também, a disseminação da ideia de homogeneidade, sem conflitos e tensões entre os diversos grupos econômicos e agentes que o compõem, dado os objetivos e metas comuns que os articulam. Enquanto objetivo econômico assume-se o lucro como sendo a essência do agronegócio. Aqui está presente a identidade de classe da burguesia e o projeto de desenvolvimento da sociedade brasileira. O agronegócio também é visto como sinônimo de avanço tecnológico, modernidade, prosperidade e superação da pobreza no meio rural. E também como o único caminho para que o país chegue à condição de Primeiro Mundo, competitivo na economia nacional, superando, inclusive, a separação entre o campo e a cidade.

No que se refere à representação da burguesia agrária no Congresso Nacional (Bruno, 2009), esta se autorrepresenta pela chamada Bancada Ruralista, que se alimenta e é alimentada por redes de sociabilidades políticas, sociais, culturais e societais. Nessa perspectiva encontra-se enraizada em toda sociedade: maçonaria, prefeituras, secretarias de estados e municípios, órgãos 
públicos, igrejas, empresas, ONGs, sindicatos, organizações comunitárias, entre outros. Erroneamente, pensa-se que os ruralistas se fazem presentes no Congresso Nacional apenas para defender os interesses mais diretamente relacionados à sua reprodução como classe - no caso, a propriedade da terra. Tão ou mais importante é fazer-se presente para defender determinada visão de mundo, de valores, de sociedade.

Assiste-se à hegemonia do agronegócio no Brasil, a qual se expressa, sobretudo, supondo-se a impossibilidade da existência de alternativas históricas além do projeto do agronegócio como se ele fosse eterno e respondesse a todos os problemas do campo. Ideologicamente, é emblemático desse processo considerar a população do campo como AGROGENTE, AGRO BRASIL, AGRO É POP, AGRO É TECH, AGRO É VIDA.

Uma marca da burguesia agrária é a orientação e a organização de sua prática de classe por meio da negação do outro (campesinato), sua desqualificação, seu apagamento, como se o outro (campesinato) só existisse em função de sua continuidade e semelhança (aspecto muito presente na cultura política do coronelismo e do sistema de colonato - a figura do agregado/ morador). Tratar o campesinato como incapaz, despreparado, sem iniciativa, ignorante, "aquele que só sabe puxar a cova para os pés", a imagem de Jeca-Tatu. Nesse sentido, nega-se também a identidade de diversas categorias do campesinato, como, por exemplo, os ribeirinhos, os pescadores/agricultores, meeiros, arrendatários, posseiros, diaristas, parceiros etc.

Um recorrente recurso da burguesia agrária continua sendo a violência. A prática da eliminação física e da pressão psicológica do campesinato, a exemplo de assassinatos, queima de barracos e pertences pessoais, destruição da produção, ameaças, torturas, prisões ilegais, perseguição, processos violentos de reintegração de posse em áreas ocupadas pelos sem-terra etc.

O uso dessa violência está expressa nos depoimentos da burguesia agrária em alguns momentos conjunturais e por suas entidades representativas, como, por exemplo: "Se é para imolar gente que comecemos logo" (Latifundiários na Nova República), "Para cada terra ocupada, um padre morto" (Latifundiários nos anos 1970-80), "Conseguimos enterrar o MST com uma pá de cal” (Associação Brasileira do Agronegócio), "Hoje sou 
avô, não mato mais mulher grávida" (Movimento Nacional de Produtores). ${ }^{6}$ Nessa perspectiva da violência, a burguesia agrária e suas organizações têm imensa dificuldade de negociar com os movimentos sociais no campo, uma vez que seu domínio é demonstrado, principalmente, pelo uso da coerção. Nessa mesma lógica utiliza-se largamente o trabalho em condições análogas à escravidão e/ou semiescravidão.

Ainda sobre as práticas da burguesia agrária, é necessário afirmar que esta não mantém a dominação política unicamente pela violência e repressão. Há que se construir hegemonia nesse processo. A defesa da desigualdade é um elemento constitutivo das relações sociais, que fortalece uma visão de propriedade da terra como direito natural, absoluto, situado acima das regras sociais. Assim, a negação dos direitos dos trabalhadores rurais anuncia a ação hegemônica de classe, momento em que a prática é orientada por constrangimentos, impossibilidade de acesso ao crédito e aos direitos sociais básicos.

A ação da burguesia aparece, ainda, em mobilizações de rua em momentos que necessitam defender seus patrimônios e interesses; através de "Tratoraço", "Caminhonaço", "Movimento Vistoria Zero", Movimento Nacional dos Produtores, associações em defesa da propriedade, vigílias, palavras de ordem, Movimento SOU AGRO. Em outros termos, a preocupação com a construção da imagem com músicas, hinos, bancada ruralista, lobbies.

Essa burguesia agrária priorizou seus investimentos em soja, milho, cana-de-açúcar (produzindo açúcar e etanol), eucalipto para celulose, pecuária bovina, fruticultura, madeira para produção de carvão, camarão de cativeiro, entre outros produtos. Além disso, essa burguesia agrária, através de suas empresas nacionais e transnacionais, domina também toda a produção de commodities agrícola, sementes, fertilizantes, agroquímicos, comércio, agroindústrias e a produção e comercialização de máquinas agrícolas.

Como analisado, o agronegócio e a burguesia agrária que o sustenta, amparado no capital financeiro, nas transnacionais e no aparato estatal, têm sido basilares para definir o movimento das classes sociais no campo e suas

6. Informações disponíveis na pesquisa sobre o patronato rural da profa. dra. Regina Bruno, 2009. 
estratégias. Uma burguesia agrária, altamente capitalizada, com tecnologia de ponta na produção agrícola, com articulações internacionais e uma rede de relações políticas, econômicas, sociais, institucionais, intimamente ligada à reprodução e acumulação do capital financeiro.

Ademais, a força de trabalho dos camponeses tem sido acessível ao mercado agrícola, "passiva" para aceitar quaisquer relações e condições de trabalho, negando um conjunto de direitos sociais já conquistados. $\mathrm{O}$ agronegócio se contrapõe à reforma agrária camponesa e popular, proposta pelos movimentos sociais rurais, num confronto permanente por fora e por dentro das estruturas do Estado.

\section{Considerações finais}

De fato a questão agrária, na atualidade, está atrelada à estratégia estatal-privada de reprodução do capital, que assegura o desenvolvimento econômico no campo, através do agronegócio, do monopólio da terra, da superexploração da força de trabalho, da exploração intensiva da produção agrícola, dada a demanda de commodities, da extração da renda fundiária e do processo de apropriação da riqueza natural e social.

Nessa mesma lógica, as terras improdutivas que antes eram designadas aos programas de reforma agrária, após processos de luta pela terra, agora também são disputadas pelo agronegócio. Ou seja, o capital financeiro e as empresas transnacionais que atuam na agricultura no mundo buscam associar-se aos proprietários de terras que possuem terras improdutivas ou com pouco investimento e muitos deles ainda considerados atrasados do ponto de vista tecnológico e produtivo. Mas estes detêm o que mais importa ao capital internacional: a terra. E deverão, num curto espaço de tempo, modernizar-se e capitalizar-se, sob pena de perder suas terras para as empresas internacionais do agronegócio, através da compra ou do arrendamento. Assim, percebe-se uma identidade de classe entre os grandes capitalistas do agronegócio e os proprietários de terras atrasados, com a cumplicidade dos governos estaduais e federal. 
Nesse modelo de agronegócio não há espaço para a agricultura familiar e a reforma agrária camponesa e popular. Vale destacar a luta pelo direito à terra que envolve um significativo número de atores sociais que se comprometem na busca de solução para o conflito agrário em favor dos sem-terra. Da perspectiva das famílias participantes desses processos de lutas, em sintonia com suas representações e aliados, estas foram capazes de gerar uma prática política que contemplou a formação das lideranças, a articulação de entidades e movimentos sociais urbanos, a mobilização de recursos financeiros e materiais, uma vivência de novos valores que poderão contribuir para a construção de outra sociabilidade.

O que se verifica, nessa realidade, é a expansão do capital no campo, pois essa é sua lei: a da reprodução e acumulação crescente e ampliada. $\mathrm{O}$ aspecto mais relevante da expansão do capital no campo é exatamente a expropriação dos trabalhadores rurais de suas terras e sua transformação em trabalhadores livres, ou seja, libertos da propriedade da terra, tendo apenas sua força de trabalho e sua capacidade de trabalhar, para se tornarem assalariados e/ou outras formas de relação de trabalho com a grande empresa capitalista rural, acrescido da renda da terra.

A luta pela terra e pela reforma agrária se insere na luta contra o modelo do capital na agricultura, na figura do agronegócio, colocando desafios mais amplos e complexos não só para os movimentos sociais do campo, mas para toda a sociedade brasileira.

A terra é um bem maior e comum a todos, porém foi apropriada privadamente para produzir. A terra não deve ser tratada como uma mercadoria, mas na lógica do capital está retida sob o domínio de poucos. É o hábitat natural da humanidade, é vida e proporciona a vida. A terra só tem sentido quando produz para toda a população sobreviver com dignidade. É urgente e necessária uma política de reforma agrária consistente, ampla, massiva, junto com uma política agrícola de apoio à pequena produção familiar e camponesa.

Por fim, pode-se afirmar que a luta pela reforma agrária que atenda às demandas dos camponeses continuará no cenário político nacional. Novas estratégias forjarão as lutas por terra e pela defesa das águas, das florestas, 
dos recursos naturais, dos povos originários, da soberania nacional. A mobilização, a resistência, a organização dos camponeses e seus movimentos sociais aproveitarão as contradições presentes no modelo capitalista em curso no campo para impulsionar as mudanças e conquistas da classe trabalhadora.

Nessa trajetória, o campesinato continuará sua longa caminhada em busca de um lugar para assentar sua vida e seus sonhos e ver os/as meninos/ as crescerem com saúde e alegria. Caminham contra a barbárie do capital financeiro na agricultura, contra a violência e a expropriação, contra a reforma agrária de mercado e o latifúndio. A alternativa é continuar a caminhada até a conquista da terra e como cantam os poetas: "[...] penso que cumprir a vida seja simplesmente compreender a marcha e ir tocando em frente [...]". ?

Recebido em 24/4/2017 - Aprovado em 17/10/2017

\section{Referências bibliográficas}

BOTTOMORE, Tom. Dicionário do pensamento marxista. Rio de Janeiro: Jorge Zahar, 2001.

BRASIL. Decreto ${ }^{\circ}$ 4.074, de 4 de janeiro de 2002. Brasília, 2002.

BRUNO, Regina. Um Brasil ambivalente: agronegócio, ruralismo e relações de poder. Rio de Janeiro: Mauad X; Seropédica: Edur, 2009.

CAMPANHA CONTRA OS AGROTÓXICOS. Caderno de formação da Campanha Permanente contra os Agrotóxicos e pela Vida, 2011.

CEPAL. Economia campesiana y agricultura empresarial. 2. ed. México: Siglo XXI, 1985.

DELGADO, Guilherme da Costa. Reestruturação da economia do agronegócio: anos 2000. In: STÉDILE, João Pedro (Org.). A questão agrária no Brasil: o debate na década de 2000. São Paulo: Expressão Popular, 2013. v. 7.

7. Trecho da música "Tocando em frente", de autoria de Almir Sater e Renato Teixeira. 
DELGADO, Guilherme da Costa. A questão agrária e o agronegócio no Brasil. In: CARTER, Miguel (Org.). Combatendo a desigualdade social: o MST e a reforma agrária no Brasil. São Paulo: Editora Unesp, 2010.

ENGELS, Friedrich. Princípios do comunismo. Disponível em: $<$ https://www.marxists. org/portugues/marx/1847/11/principios.htm>. Acesso em: 26 jul. 2014.

FERNANDES, Bernardo Mançano. A Reforma Agrária que o governo Lula fez e a que pode ser feita. In: SADER, Emir (Org.). Lula e Dilma: 10 anos de governos pós-neoliberais no Brasil. São Paulo: Boitempo; Rio de Janeiro: Flacso Brasil, 2013.

IBGE. Censo Agropecuário, 2006.

OLIVEIRA, Ariovaldo Umbelino. A questão agrária no Brasil: não reforma e contrareforma agrária no governo Lula. In: MAGALHÃES, João Paulo de Almeida. Os anos Lula: contribuições para um balanço crítico 2003-2010. Rio de Janeiro: Garamond, 2010.

. Barbárie e modernidade: as transformações no campo e o agronegócio no Brasil. In: STEDILE, João Pedro. (Org.). A Questão Agrária no Brasil. O Debate na década de 2000. V. 7. São Paulo: Expressão Popular, 2013.

STÉDILE, João Pedro (Org.). A questão agrária no Brasil: o debate na década de 2000. São Paulo: Expressão Popular, 2013. V. 7.

VEIGA, José Eli. “A dimensão rural do Brasil”. In: STEDILE, João Pedro. (Org.). A Questão Agrária no Brasil: O Debate na década de 2000. V. 7. São Paulo: Expressão Popular, 2013. 